\title{
E-Perm Alpha Surface Monitor
}

by

V. Fricke

Westinghouse Savannah River Company

Savannah River Site

Aiken, South Carolina 29808

C. May

-

S. Salaymeh

This paper was prepared in connection with work done under the above contract number with the U.S. Department of Energy. By acceptance of this paper, the publisher and/or recipient acknowledges the U. S. Government's right to retain a nonexclusive, royalty-free license in and to any copyright covering this paper, along with the right to reproduce and to authorize others to reproduce all or part of the copyrighted paper. 


\section{E-PERM ${ }^{\circledR}$ Alpha Surface Monitor}

Deactivation and Decommissioning Focus Area

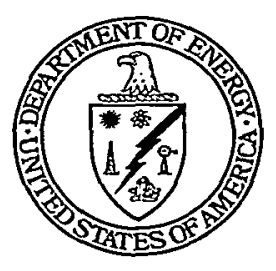

Prepared for U. S. Deparțment of Energy Office of Environmental Management Office of Science and Technology

December, 1999 


\section{DISCLAIMER}

This report was prepared as an account of work sponsored by an agency of the United States Government. Neither the United States Government nor any agency thereof, nor any of their employees, makes any warranty, express or implied, or assumes any legal liability or responsibility for the accuracy, completeness, or usefulness of any information, apparatus, product or process disclosed, or represents that its use would not infringe privately owned rights. Reference herein to any specific commercial product, process or service by trade name, trademark, manufacturer, or otherwise does not necessarily constitute or imply its endorsement, recommendation, or favoring by the United States Government or any agency thereof. The views and opinions of authors expressed herein do not necessarily state or reflect those of the United States Government or any agency thereof.

This report has been reproduced directly from the best available copy.

Available for sale to the public, in paper, from: U.S. Department of Commerce, National Technical Information Service, 5285 Port Royal Road, Springfield, VA 22161, phone: (800) 553-6847

fax: (703) 605-6900

email: orders@ntis.fedworld.gov

online ordering: http://www.ntis.gov/ordering.htm

Available electronically at http://www.doe.gov/bridge

Available for a processing fee to U.S. Department of Energy and its contractors, in paper, from: U.S. Department of Energy, Office of Scientific and Technical Information, P.O. Box 62, Oak Ridge, TN 37831-0062, phone: (865) 576-8401

fax: (865) 576-5728

email: reports@adonis.osti.gov 


\section{DISCLAIMER}

Portions of this document may be illegible in electronic image products. Images are produced from the best available original document. 

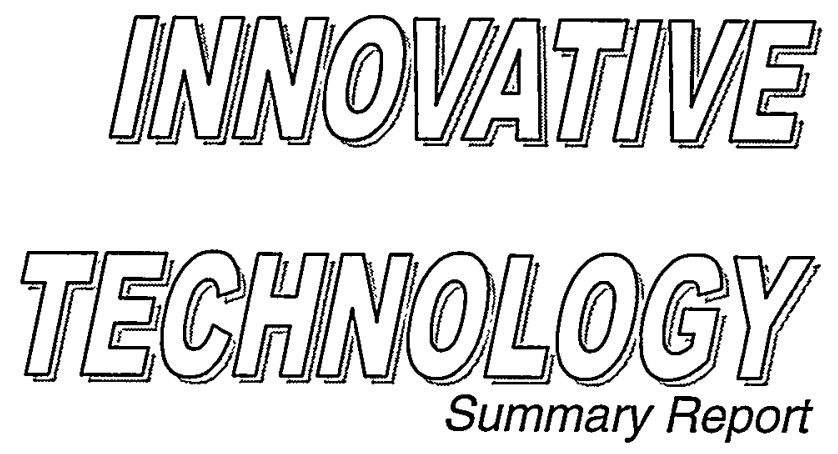

\section{E-PERM ${ }^{\circledast}$ Passive Electret Ion Chamber}

OST Reference \# 2315

Deactivation and Decommissioning Focus Area

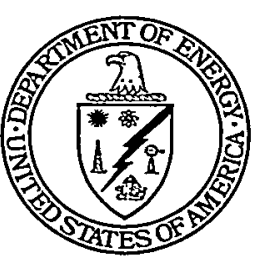

Demonstrated at 321-M Fuel Fabrication Facility Large-Scale Demonstration and Deployment Project Savannah River Site Aiken, South Carolina 
WSRC-TR-99-00460 


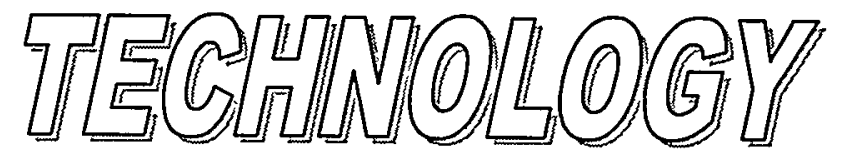

Summary Report

\section{Purpose of this document}

Innovative Technology Summary Reports are designed to provide potential users with the information they need to quickly determine if a technology would apply to a particular environmental management problem. They are also designed for readers who may recommend that a technology be considered by prospective users.

Each report describes a technology, system, or process that has been developed and tested with funding from DOE's Office of Science and Technology (OST). A report presents the full range of problems that a technology, system, or process will address and its advantages to the DOE cleanup in terms of system performance, cost, and cleanup effectiveness. Most reports include comparisons to baseline technologies as well as other competing technologies. Information about commercial availability and technology readiness for implementation is also included. Innovative Technology Summary Reports are intended to provide summary information. References for more detailed information are provided in an appendix.

Efforts have been made to provide key data describing the performance, cost, and regulatory acceptance of the technology. If this information was not available at the time of publication, the omission is noted.

All published Innovative Technology Summary Reports are available on the OST web site at http://OST.em.doe.gov under "Publications." 


\section{TABLE OF CONTENTS}

1 SUMMARY

2 TECHNOLOGY DESCRIPTION 5

3 PERFORMANCE $\quad 8$

4 TECHNOLOGY APPLICABILITY AND ALTERNATIVES

$5 \operatorname{cost} \quad 13$

6 REGULATORY AND POLICY ISSUES 17

7 LESSONS LEARNED 18

APPENDICES

A References $\quad 19$

B Technology Cost Comparison 20

C Acronyms and Abbreviations $\quad \mathrm{XX}$ 


\section{SECTION 1}

\section{SUMMARY}

The E-PERM ${ }^{\oplus}$ Alpha Surface Monitor is an integrating electret ion chamber innovative technology used to measure alpha radiation on surfaces of materials. The technology is best used on surfaces with low contamination levels such as areas with potential for free release, but can also be used in areas with higher levels of contamination. Measurement accuracy and production of the E-PERM ${ }^{\circledast}$ Alpha Surface Monitor compared favorably with the baseline technology. The innovative technology cost is approximately $38 \%$ higher than the baseline with an average unit cost per reading costing $\$ 6.04$ vs. $\$ 4.36$; however, the flexibility of the E-PERM ${ }^{\circledR}$ Alpha Surface Monitor may offer advantages in ALARA, reduction of operator error, waste minimization, and measurement accuracy.

\section{Technology Summary}

The E-PERM ${ }^{\circledast}$ Alpha Surface Monitor is a small, stand alone, integrating electret ion chamber (EIC) used to measure alpha radiation on surfaces of materials. The system is composed of a small ion chamber with a mylar window to contain the ions produced by the interaction of alpha radiation with air and a sensor to collect and measure the ions produced. A separate microprocessor provides the hardware to measure and process data.

\section{Problem}

Many Department of Energy sites have a need to quickly and cheaply characterize surfaces for uranium, plutonium, and other alpha emitting radionuclides. A method that minimizes waste, reduces personnel exposure, and reduces costs is needed to efficiently characterize excess facilities.

\section{How It Works}

When ionizing alpha radiation from a contaminated surface enters an electret ion chamber, the radiation causes ionization by stripping electrons from atoms of air in the chamber. The ejected electrons are attracted to a positively charged piece of Teflon ${ }^{\circledR}$, called the electret, mounted inside an ion chamber. The electrons collect on the surface of the electret and neutralize its charge. After the designated exposure time has elapsed, the electret is removed from the chamber. Using a portable charge reader, the electret's final voltage is read. The difference in the electret's initial and final voltages is a function of exposure time and the alpha contamination level to which the chamber has been exposed. After the charge reader measures the change in the electret's voltage, this data is used to calculate the contamination level. Data can be downloaded to a personal computer to provide databases and aid in reporting.

\section{Potential Markets}

In addition to SRS, Oak Ridge National Laboratory, Rocky Flats, Fernald, the Nevada Test Site, Hanford, and the Tonopah Test Range have the need to characterize surfaces with alpha producing radionuclides. 


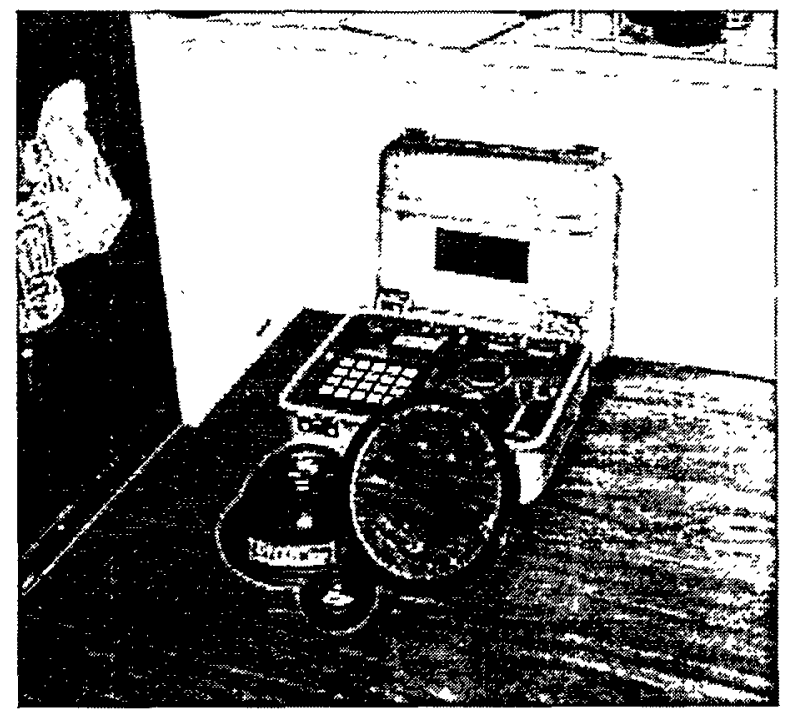

Figure 1. SPER2 Microprocessor, electret, and $180 \mathrm{~cm}^{2}$ ion chamber.

\section{Advantages Over the Baseline}

The baseline technology is the hand probe and smear method. The advantages of the E-PERM ${ }^{\circledR}$ Alpha Surface Monitor are:

- Simple to use and analyze. Semiskilled technician sufficient.

- Small size and weight. Units can be easily located in difficult-to-reach areas. Units can be placed on floors, walls, and ceilings.

- Minimizes personnel exposure. Units can be set in position and left until exposure time is complete. Technician does not stay in radiation area during survey.

- Eliminates operator error and fatigue.

- Microprocessor collects, stores, and analyzes data to make reporting easier and quicker.

- Robust technology. The electrets are unaffected by shock, humidity, and temperature.

\section{Limitations of Technology}

Surfaces where the EICs are placed should be relatively flat and smooth to form an enclosed space with the EIC. Gaps between the EIC and surface being monitored may cause erroneous readings. 


\section{Demonstration Summary}

The E-PERM ${ }^{\circledast}$ Alpha Surface Monitor demonstration was held in the 321-M Fuel Fabrication Facility located at the Savannah River Site (SRS) during the period June 16, 1999 to August 24, 1999. The 321-M facility was used to manufacture fuel and target assemblies for irradiation in the site production reactors. The facility was de-inventoried in 1995, leaving the process area a high contamination area, contaminated with highly enriched uranium. Other parts of the building remain posted radiological areas with lower levels of contamination. Some overhead areas have - low level contamination. During deactivation of the facility, surveys are necessary to establish the contamination levels in the facility.

\section{Key Results}

The key results of the innovative technology demonstration are:

- Measurements with the EICs showed satisfactory agreement with the baseline technology and NIST traceable standards.

- Productivity was approximately the same as the baseline; however, productivity should increase in surveys with large numbers of readings.

- The cost of performing characterization work with the EICs is higher on the average than the baseline.

- In addition to those advantages listed above, there is no radioactive waste produced and measurement accuracy can be improved with longer exposure times if necessary.

- The EICs are most efficient in areas where access with the baseline technology is difficult or limited (e.g., overheads, gloveboxes) and for final surveys using the MARSSIM guidelines.

\section{Regulatory/Policy Issues}

None

\section{Availability}

The E-PERM ${ }^{\circledast}$ Alpha Surface Monitor is available from Rad Elec Inc.

\section{Future Plans}

The E-PERM ${ }^{\oplus}$ Alpha Surface Monitor technology will become an alternative to the hand probe and smear method of characterization at SRS. The technology may be used when technology capabilities meet job requirements and objectives.

\section{Contacts}

\section{Technical}

Jeffrey Lee, Westinghouse Savannah River Company, (803) 725-0652; jeffreyw.lee@srs.gov Cecil May, Savannah River Technology Center, (803) 725-5813; cecil.may@srs.gov Saleem Salaymeh, Savannah River Technology Center, (803) 725-1628; saleem.salaymeh@srs.gov Vito Casella, Savannah River Technology Center, (803) 725-1302; vito.casella@srs.gov Lorin Stieff, Rad Elect Inc., (301) 949-9508; Istieff@aol.com 


\section{Management}

Cecil May, Test Engineer, Westinghoușe Savannah River Company, (803) 725-5813, cecil.may@srs.gov]

John Pierpoint, Project Manager, Westinghouse Savannah River Company, (803) 725-0649, john.pierpoint@srs.gov

\section{1-M Large-Scale Demonstration and Deployment Project}

Martin Salazar, U.S. Department of Energy, Savannah River Operations Office; (803) 557-3617; martin.salazar@srs.gov

George Mishra, U.S. Department of Energy, Savannah River Operations Office; (803) 725-7239; george.mishra@srs.gov

John Duda, Federal Energy Technology Center, (304) 285-4217, jduda@fetc.doe.gov

\section{Licensing Information}

No licensing or permitting activities were required to support this demonstration.

\section{Web Site}

The 321-M LSDDP Internet address is http://www.srs.gov/general/srtech/lstd/index.htm

Other

All published Innovative Technology Summary Reports are available online at http://em50.em.doe.gov. The Technology Management System, also available through the EM50 Web site, provides information about OST programs, technologies, and problems. The OST Reference \# for the E-PERM ${ }^{\circledast}$ Alpha Surface Monitor technology is 2315. 


\section{TECHNOLOGY DESCRIPTION}

\section{Overall Process Definition}

The E-PERM ${ }^{\circledast}$ alpha monitor is a small, stand alone, integrating electret ionization chamber (EIC). The E-PERM ${ }^{\oplus}$ alpha monitor consists of:

- An electret

- The ion chamber housing

- A portable electret voltage reader

When ionizing alpha radiation from a contaminated surface enters the ion chamber through a thin aluminized mylar window, the radiation causes ionization by stripping electrons from atoms of air in the chamber. The ejected electrons are attracted to the electret mounted inside the ion chamber. The electrons collect on the surface of the electret and over time partially neutralize the initial charge.

After the designated exposure time has elapsed, the electret is removed from the chamber and its final voltage is measured using an electret charge reader. The difference in the electret's initial and final voltages is a function of the alpha contamination level it has been exposed to and the time of the exposure. The voltage drop and exposure time are converted to contamination levels by either a hand-held computer or a microprocessor reader that can provide immediate contamination levels in $\mathrm{dpm} / 100 \mathrm{~cm}^{2}$.

\section{Electret}

The electret is a positively charged Teflon $^{\circledR}$ disc that serves as both the source of an electrostatic field and a sensor. The electrets are very stable and are unaffected by shock, humidity, temperature, and will hold charges for long period of times if not exposed to ionizing radiation. The electret is available in the following thicknesses and sensitivities:

- $0.127 \mathrm{~mm}$ (long-term exposure, low sensitivity)

- $1.524 \mathrm{~mm}$ (standard sensitivity)

- $4.572 \mathrm{~mm}$ (short-term exposure, high sensitivity)

Each electret can be used for multiple measurements. The number of measurements depends on the voltage drop for each measurement. Each electret has an initial charge of approximately 700 volts and can be used down to approximately 200 volts. Acceptable readings can be made with a minimum drop of 15-20 volts. During the demonstration, a 30-volt drop gave accurate measurements. In general, the higher the voltage drop, the better the accuracy. Once the electret has been discharged, it cannot be recharged and must be discarded.

\section{Ion Chamber}

The ion chamber provides a holder for the electret and a chamber for containing the ions produced by the alpha radiation. Ion chambers are available in two sizes: 1) $48 \mathrm{~cm}^{2}$, and 2) 180 $\mathrm{cm}^{2}$. The chambers are made of electrically conducting plastic and have windows covered with a thin aluminized mylar film to protect the electret from dust and other particles. Other materials may be used as window covers for background measurements and measurements of other radionuclides. 


\section{Electret Voltage Reader}

There are two electret voltage readers available. A hand held reader, called the SPER1 is suitable for relatively small numbers of electret measurements. It is easily protected from contamination in contaminated areas. The voltage readings, electret serial numbers, locations, deployment times, and radiation levels must be manually recorded and calculated.

The SPER2 Microprocessor Electret Reader is designed to manage data associated with large numbers of measurements. The reader is combined with a barcode reader and computer hardware that stores measurement data. The data can be downloaded to a personal computer $(\mathrm{PC})$ to calculate radiation levels and create databases and reports. The unit is packaged in a rugged case and can be used in the field for onsite measurement. It is not recommended to take the unit into highly contaminated areas.

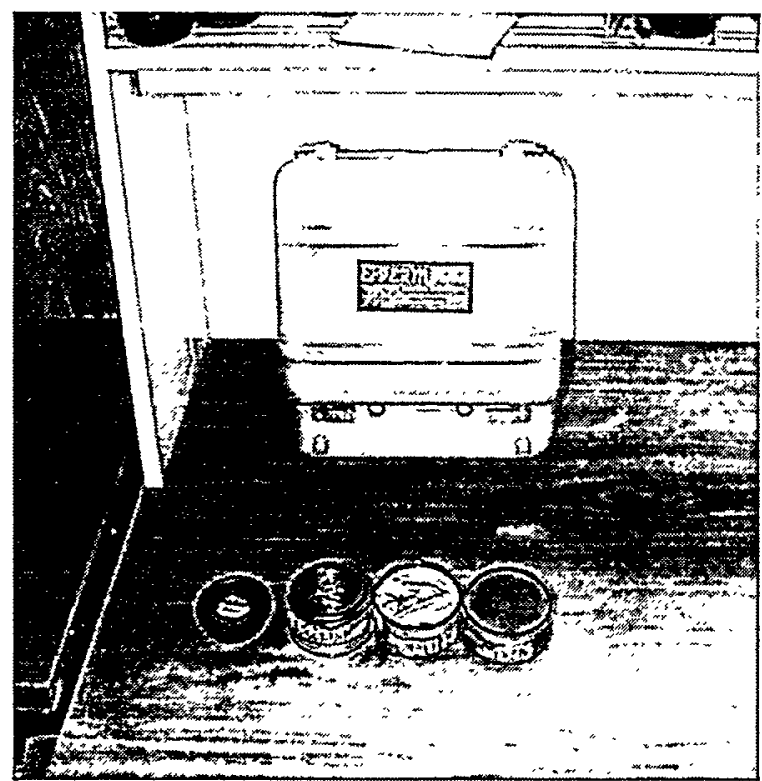

Figure 2. SPER2 Microprocessor, electret, and $48 \mathrm{~cm}^{2}$ ion chambers

\section{Goals and Objectives}

The goals and objectives of the E-PERM ${ }^{\circledast}$ demonstration were to:

- locate and quantify HEU contamination in selected areas in $321 \mathrm{M}$

- compare and evaluate against the baseline hand probe and smear surveys

- provide sufficient data for deployment at SRS and within the DOE complex

The E-PERM ${ }^{\circledast}$ technology has potential for use at any DOE facility that has alpha contaminated surfaces.

\section{System Operation}

The E-PERM ${ }^{\oplus}$ EIC is a passive detector that requires no external electrical power or batteries. The ionization chambers, with electrets installed, are small, lightweight chambers that can be easily affixed to most flat surfaces. The $48 \mathrm{~cm}^{2}$ ionization chambers are approximately $15 / 8$ in. $(4 \mathrm{~cm})$ high by $31 / 4$ in. $(8 \mathrm{~cm})$ in diameter. The $180 \mathrm{~cm}^{2}$ chambers are approximately $31 / 4 \mathrm{in}$. (8 $\mathrm{cm}$ ) high by $75 / 16$ in. $(19 \mathrm{~cm})$ in diameter. The chambers and electrets weigh only 6 to 8 ounces.

A typical sequence of activities to measure alpha contaminated surfaces is as follows:

1. Make initial electret voltage readings using SPER2 data logging reader and barcode reader. This initial reading records the electret serial number, location, initial voltage, and initial time. The time can also be manually entered to accurately record the electret placement time.

2. Load electrets into the ion chambers. 
3. Determine approximate exposure time and deploy detectors at selected locations. Record electret serial number and location. Exposure times will depend on the radiation level. A few hours will be sufficient in areas with higher radiation levels. For very low levels, overnight exposures may be used. In these cases, the detectors may be deployed in the afternoon and removed the next morning.

4. After exposure time has elapsed, collect detectors. Electrets should either be removed from the ion chambers or covers placed on the chambers to prevent additional exposure of the electret.

5. Make final electret voltage readings using SPER2 data logging reader and barcode reader. The final reading provides the final voltage readings and times required to compute the radiation levels.

6. Connect the SPER2 reader to a PC and download data for reporting purposes.

7. For every 10 detectors deployed, one beta/gamma background detector should be deployed and analyzed the same way as the other detectors.

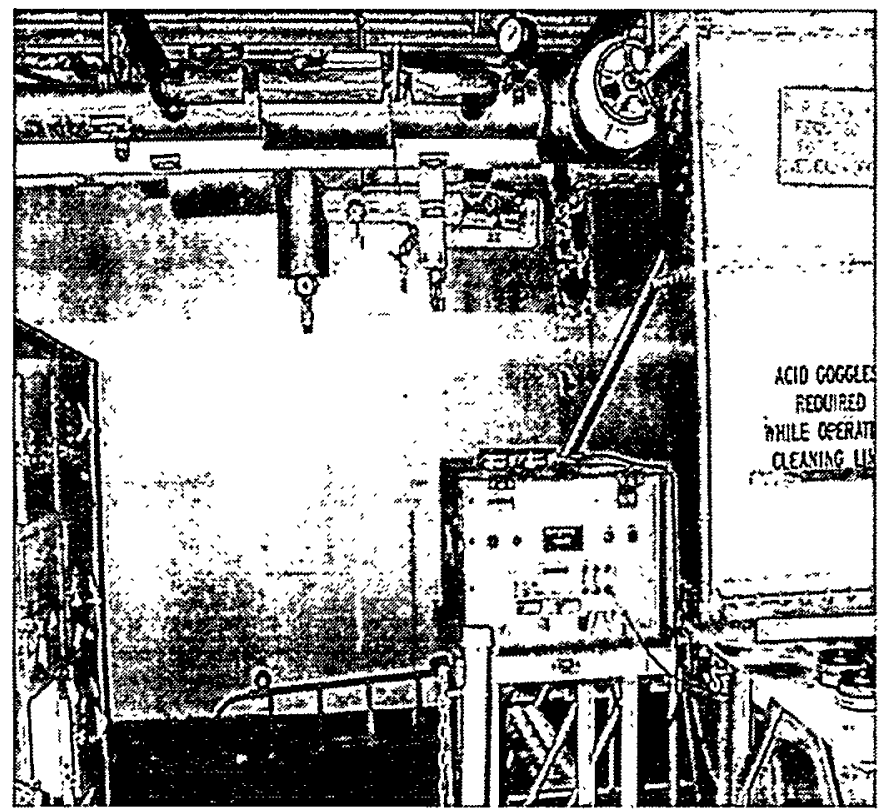

Figure 3. Electret lon Chamber placed in Tube Cleaning Room

\section{Manpower Skills and Training Requirements}

The EICs and SPER2 microprocessor are simple and easy to use and require no special operator training. A short orientation session given by the manufacturer and lasting approximately two hours is normally required.

\section{Secondary Waste}

The electrets do not normally come in contact with contaminated surfaces. Spent electrets would normally be clean waste. The ion chambers may be contaminated on the external surfaces in contact with contamination. The chambers are not contamination resistant and may be decontaminated if necessary. If decontamination is not possible, the ion chambers may become low level waste. There is no hazardous waste created by the technology. 


\section{SECTION 3}

\section{PERFORMANCE}

\section{Demonstration Plan}

The demonstration of the E-PERM ${ }^{\circledast}$ alpha monitor was performed in the following locations in Building 321-M:

- Component cleaning room

- Tube cleaning room

- Billet Assembly and Weld Area

- Overhead ducts, electrical, and structure

The component cleaning room is a contamination area (CA). The tube cleaning room and billet assembly and weld area are posted as radiological buffer areas (RBA). The building overheads have isolated contamination areas.

In the component cleaning room and tube cleaning room, surveys were repeated with both the 48 $\mathrm{cm}^{2}$ and $180 \mathrm{~cm}^{2}$ ionization chambers for comparison. Each size was deployed in identical locations to compare final readings and deployment times.

\section{Performance Objectives}

The primary objectives of this demonstration were to evaluate the capabilities and performance of the E-PERM ${ }^{\circledast}$ alpha monitor. The elements of the demonstration were:

- Locate and quantify HEU contamination in selected areas in $321 \mathrm{M}$

- Compare and evaluate against the baseline hand probe and smear surveys

- Provide sufficient data for deployment at SRS and within the DOE complex

\section{Results}

Results were evaluated for the following studies:

a) In the component cleaning room and tube cleaning room, surveys were repeated with both the $48 \mathrm{~cm}^{2}$ and $180 \mathrm{~cm}^{2}$ ionization chambers for comparison;

b) Contamination of ten hot areas in the component cleaning room was measured with the 48 $\mathrm{cm}^{2}$ and $180 \mathrm{~cm}^{2}$ ionization chambers, and the measurements were evaluated against contamination estimates from baseline hand probe surveys; and

c) The precision of measurements with the $48 \mathrm{~cm}^{2}$ and $180 \mathrm{~cm}^{2}$ ionization chambers was determined using standard sources. 


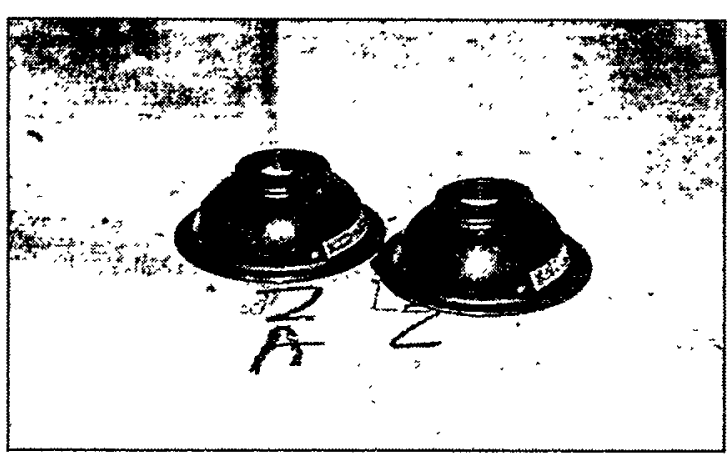

Figure 4. Positioning of Large Chamber EICs in Component Cleaning Room.
Alpha measurements were performed with both the $48 \mathrm{~cm}^{2}$ and $180 \mathrm{~cm}^{2}$ ionization chambers in the component cleaning room and tube cleaning room. Each size was deployed at the same locations to compare final readings and deployment times. Twentyfive chambers and three background chambers of each size were used to measure twenty-five locations in each room. The background chambers contained a carbon coated Tyvek window to remove alpha radiation. The exposure time for the $48 \mathrm{~cm}^{2}$ chambers was 22 hours, while the $180 \mathrm{~cm}^{2}$ chambers were exposed for 6 hours.

A comparison of results for the small and large electret ionization chambers is shown in Table 1. Since the large chambers (LC) measured about four times the area that the small chambers (SC) measured, the results are not directly comparable. Both chambers verified that the contamination was below $100 \mathrm{dpm}$ alpha $/ 100 \mathrm{~cm}^{2}$ for forty-six of these areas. Also, both chambers measured the contamination levels for four of the areas to be above $100 \mathrm{dpm}$ alpha/100 $\mathrm{cm}^{2}$ with agreement to within a factor of two (SC/LC =1.5). This agreement is considered acceptable, since different areas of the same location are being measured.

Table 1. Comparison of Large Chamber (LC) and Small Chamber (SC) EIC Results for the Component Cleaning Room (CCR) and Tube Cleaning Room (TCR)

\begin{tabular}{|c|c|c|c|c|}
\hline Area Surveyed & $\begin{array}{c}\text { Average } \\
\text { Results SC } \\
\left(\mathrm{dpm} / 100 \mathrm{~cm}^{2}\right)\end{array}$ & $\begin{array}{c}\text { Average } \\
\text { Results LC } \\
\left(\mathrm{dpm} / 100 \mathrm{~cm}^{2}\right)\end{array}$ & $\begin{array}{c}\text { SC/LC } \\
\text { Data }(4)>100 \\
\text { dpm } / 100 \mathrm{~cm}^{2}\end{array}$ & $\begin{array}{c}\text { Average } \\
\text { Probe Survey } \\
\left(\mathrm{dpm} / 100 \mathrm{~cm}^{2}\right)\end{array}$ \\
\hline CCR (25 low alpha locations) & 77 & 73 & 1.5 & \\
\hline TCR (25 low alpha locations) & 11 & 13 & & \\
\hline CCR (10 hot areas) & 654 & 780 & & 724 \\
\hline
\end{tabular}

Contamination of ten hot areas in the component cleaning room was measured with the $48 \mathrm{~cm}^{2}$ and $180 \mathrm{~cm}^{2}$ ionization chambers, and the measurements were evaluated against contamination estimates from baseline hand probe surveys. Background measurements were performed at the locations where the ambient radon and gamma radiation was high enough to contribute to the response of the electret ionization chambers. Again, since the large chambers measured about four times the area that the small chambers measured, the results are not directly comparable.

In general, the electret ionization chamber (EIC) results showed about the same level of contamination as the hand probe surveys. In a few instances, the agreement between the hand probe and EIC results showed a variation greater than a factor of two, but this would be expected since the contamination is not uniformly distributed in these areas.

The $48 \mathrm{~cm}^{2}$ ionization chamber had advantages of a lower background and less sensitivity for high-level contamination measurements. However, the $180 \mathrm{~cm}^{2}$ ionization chamber had advantages of a shorter exposure time, a larger measurement area and was more sensitive for low level contamination areas.

Based on duplicate measurements of NIST traceable standard alpha sources, the measurement precision for voltage changes of about 40 volts was determined to be better than $3 \%$ for the 48 $\mathrm{cm}^{2}$ chambers and better than $4 \%$ for the $180 \mathrm{~cm}^{2}$ chambers. 
Both the $48 \mathrm{~cm}^{2}$ and $180 \mathrm{~cm}^{2}$ ionization chambers were able to show that contamination was below $100 \mathrm{dpm} / 100 \mathrm{~cm}^{2}$ alpha (uranium-235), and the results showed satisfactory agreement with estimates from hand probe surveys. Results from these studies support the potential use of this technology as a method to measure alpha (U-235) surface contamination at SRS and within the DOE complex. 


\section{SECTION 4}

\section{TECHNOLOGY APPLICABILITY \\ AND ALTERNATIVES}

\section{Competing Technologies}

The hand probe and smear method is the baseline technology usually selected for measuring alpha contamination on material surfaces.

Hand probe and smear method disadvantages:

- Accuracy is dependent on operator technique. Probe scanning speed and distance to the surface being scanned determine the accuracy of the method. Sensitivity decreases markedly when scan speed and distance is increased.

- Probing of large surface areas may become tedious and prone to operator error. Accuracy may decline after several hours of surveying.

- The alpha scintillation detectors used in hand probing are fragile. The mylar window is easily punctured and requires replacement. Calibration and maintenance are routine tasks.

- Hand probe and smear is a slow process requiring manpower to scan, count smears, and write reports.

\section{Technology Applicability}

The E-PERM ${ }^{\oplus}$ EIC technology addresses the disadvantages of the baseline technology. The EIC eliminates the potential inaccuracies caused by operator technique and has potential for reducing the overall manhours required for the surveying process. Since the EICs are passive detectors, they can be placed in position and left until the monitoring time is complete. An operator does not remain in the area and is free to perform other work. Data is stored in the SPER2 microprocessor during the initial and final voltage readings. The data can be downloaded to a PC and used to reduce the manhours required to manually create final survey reports. Additional advantages and benefits of the EICs are shown in Table 2.

Measurement applications include:

- Measurement of contaminated surfaces and swipes

- Qualifying measurements for free release of contaminated sites

- Secondary verification of other monitoring systems

- Ideal for monitoring large areas using the Multi-Agency Radiation Survey and Site Investigation Manual (MARSSIM) guidelines 
Table 2. Advantages of E-PERM ${ }^{\oplus}$ ALPHA SURFACE MONITOR

\begin{tabular}{|c|c|c|}
\hline FEATURE & ADVANTAGES & BENEFITS \\
\hline Passive Detector & No moving parts or batteries & $\begin{array}{l}\text { Low equipment costs. In situ } \\
\text { measurements. Electrets can } \\
\text { be used numerous times. Ion } \\
\text { chambers can be used } \\
\text { indefinitely. }\end{array}$ \\
\hline Integrated Measurements & Detect low radiation levels & $\begin{array}{l}\text { Extended measurements } \\
\text { Free release limits }\end{array}$ \\
\hline Robust Technology & $\begin{array}{l}\text { Unaffected by shock, humidity, } \\
\text { and temperature }\end{array}$ & $\begin{array}{l}\text { Measurement possible in all } \\
\text { environments }\end{array}$ \\
\hline Simple to use and analyze & $\begin{array}{l}\text { Semi-skilled technicians } \\
\text { sufficient }\end{array}$ & Low cost per measurement \\
\hline Small size and weight & $\begin{array}{l}\text { Can be easily located in } \\
\text { difficult to access areas }\end{array}$ & $\begin{array}{l}\text { Can be used on floors, } \\
\text { ceilings, wall, and on } \\
\text { equipment. }\end{array}$ \\
\hline Universality & $\begin{array}{l}\text { Same reader and sensors } \\
\text { usable for making other } \\
\text { related measurements }\end{array}$ & $\begin{array}{l}\text { More price competitive when } \\
\text { used for multiple purposes }\end{array}$ \\
\hline Faster, cheaper, and safer & $\begin{array}{l}\text { Several hundreds of detectors } \\
\text { can be read and deployed in a } \\
\text { short time using a single } \\
\text { reader. Data can be analyzed } \\
\text { in a short time }\end{array}$ & $\begin{array}{l}\text { No need for operator to be in } \\
\text { radiation area during } \\
\text { measurements. No } \\
\text { radioactive waste generated } \\
\text { during use. }\end{array}$ \\
\hline
\end{tabular}

\section{Other Applications}

The E-PERM ${ }^{\circledast}$ radon monitor uses the same EICs as the alpha monitor and is widely used in the United States, Europe, and South Africa for measuring radon levels in buildings. The electrets may also be used with a beta chamber that can distinguish and characterize beta radiation.

\section{Patents/Commercialization/Sponsor}

The E-PERM ${ }^{\oplus}$ Alpha Surface Monitor is commercially available from Rad Elec Inc. Rad Elec Inc. holds the basic patent, 4,853,536(1898), and related patents for the E-PERM ${ }^{\oplus}$ technology. 


\section{SECTION 5}

\section{COST}

\section{Introduction / Methodology}

This cost analysis compares the innovative E-PERM ${ }^{\circledast}$ Alpha Surface Monitor technology with the baseline probe and smear technology. These two comparable technologies characterize and measure contamination levels. Both technologies were demonstrated at DOE-Savannah River Site (SRS) and the data was recorded. The innovative technology uses electret ionization chambers $(E I C)$ and an electret reader. The baseline technology uses a hand probe and swipe of the surface to determine contamination levels.

The cost analysis was based on recorded data performance of both innovative and baseline technologies. This analysis presents realistic estimates that represent actual characterization work within SRS. The site demonstration of the innovative technology was based on data recorded by the EIC. The data was collected on site during the Large Scale Demonstration and Deployment Project (LSDDP) at building 321-M. Descriptions contained in later portions of this analysis detail any changes to the observed data.

The cost analysis compares the two characterization technologies: an innovative E-PERM ${ }^{\boxplus}$ technology and a conventional characterization method using the probe and smear method. Cost and performance data was collected for each technology during their respective demonstrations. The following cost elements were identified from the Hazardous, Toxic and Radioactive Waste Remedial Action Work Breakdown Structure (WBS) and Data Dictionary (HTRW RA WBS), US Army Corps of Engineers. Data was collected to support a cost analysis based on those elements:

- mobilization

- characterization

- demobilization

Mobilization costs include the costs of initial electret readings and transporting technology equipment to the work area. It includes any calibration and operational checks necessary for routine use.

Characterization includes all direct and indirect activities associated with performing characterization work, placing and removing EICs, reading EICs, recording data, and reporting.

Demobilization includes clearing equipment from radiological areas and removal from the work area.

Personal Protective Equipment (PPE) costs are included in this demonstration. Two sets of PPEs are required when using EICs in contamination areas; one set to deploy the EICs, and one set to retrieve them.

\section{Cost Analysis}

Data was collected during the demonstrations for the cost elements. Work was measured and unit costs determined on the basis of reading/measurements per hour. For each element, detailed costs were determined from the data collected. 
Labor rates used in the innovative technology analysis were those in effect for the SRS site labor agreement. There was no contaminated waste disposal required for this demonstration. Crews for the various activities were based on the recorded data. Indirect costs were omitted from the analysis, since overhead rates can vary greatly among contractors. Engineering, quality assurance, administrative costs and taxes were also omitted from the analysis. Adding site specific indirect costs to produce a site-specific unit cost that includes indirect costs can modify the bare unit costs determined by the analysis.

Capital equipment costs for the innovative and baseline technologies are based on the cost of ownership. The cost of the ion chambers and reader is $\$ 8,730.00$ with a useful life range of 5 to 10 years. This report will assume a 10-year useful life. No information was collected to determine the projected time of use per year. The following assumptions are made to assign equipment cost dollar figure to the project: 1) expected useful life of the new technology equipment is 10 years; 2) equipment is operated 8 hours per day, 5 days a week for 50 weeks a year. Based on these assumptions, the extended cost per hour of operation would be approximately $\$ 0.44$. The baseline technology probe equipment is considered as overhead cost and is included in the Health Protection labor rate.

The cost of electrets depends on the number of electrets purchased and the number of times used. For this demonstration, 56 were purchased at a cost of $\$ 17.00$ per electret. Each electret can be used a number of times depending on the voltage drop of each reading. An average of fifteen readings per electret was used to determine electret cost for each measurement. This gives an average cost of $\$ 1.13$ per reading. The cost of 56 electrets was prorated based on the 178 measurements taken during the demonstration.

The electret costs are based on the quantity purchased. The current unit cost ranges from $\$ 25.00$ to $\$ 13.50$ each. The lowest cost is based on the purchase of 500 units. Electret costs for surveys with a large number of readings could be reduced by up to $20 \%$ depending on the number of electrets purchased.

The productivity for the two technologies is approximately the same, at 16 readings per hour each. The innovative technology is based on $178 \mathrm{EIC}$ readings and the baseline technology is based on 207 probe and smear readings.

The readings per hour for the EICs are based on the manhours required for the initial electret readings, deployment, pickup, and final readings. Vendor experience shows that the number of readings per hour can be increased on projects with large number of readings. Manhours will be reduced with experience in using the process. Production can be significantly increased when performing final surveys using the MARSSIM guidelines.

A comparison of the unit cost elements is shown in Table 3 . The mobilization and demobilization cost are not included in the summary unit costs and the units are expressed in readings per hour.

Table 3. Summary Unit Cost Comparison

\begin{tabular}{|l|c|c|l|l|l|}
\hline \multicolumn{2}{|c|}{ EPERM } & \multicolumn{3}{c|}{$\begin{array}{c}\text { Probe and Smear } \\
\text { (Bnnovelogative Technology) }\end{array}$} \\
\hline Cost Element & $\begin{array}{l}\text { Unit } \\
\text { Cost }\end{array}$ & $\begin{array}{c}\text { Production } \\
\text { Rate }\end{array}$ & Cost Element & $\begin{array}{l}\text { Unit } \\
\text { Cost }\end{array}$ & Production Rate \\
\hline $\begin{array}{l}\text { Characterization } \\
\text { Work }\end{array}$ & $\$ 6.04$ & 16 Readings/Hr & $\begin{array}{l}\text { Characterization } \\
\text { Work }\end{array}$ & $\$ 4.36$ & 16 Readings $/ \mathrm{Hr}$ \\
& & & & \\
\hline
\end{tabular}


Figure 5 is a cost comparison for the innovative and baseline technologies demonstration at SRS. Both technologies are based on the purchase of the equipment. The cost of the capital investment will differ somewhat in each of the two technologies. Figure 6 is a projected cost comparison of the innovative and baseline technologies ranging from 100 to 5000 readings. The estimated cost for both technologies are spread over their useful life.

The cost of performing the characterization work was found to be lower on the average in the baseline technology, when the mobilization and demobilization cost were not included.

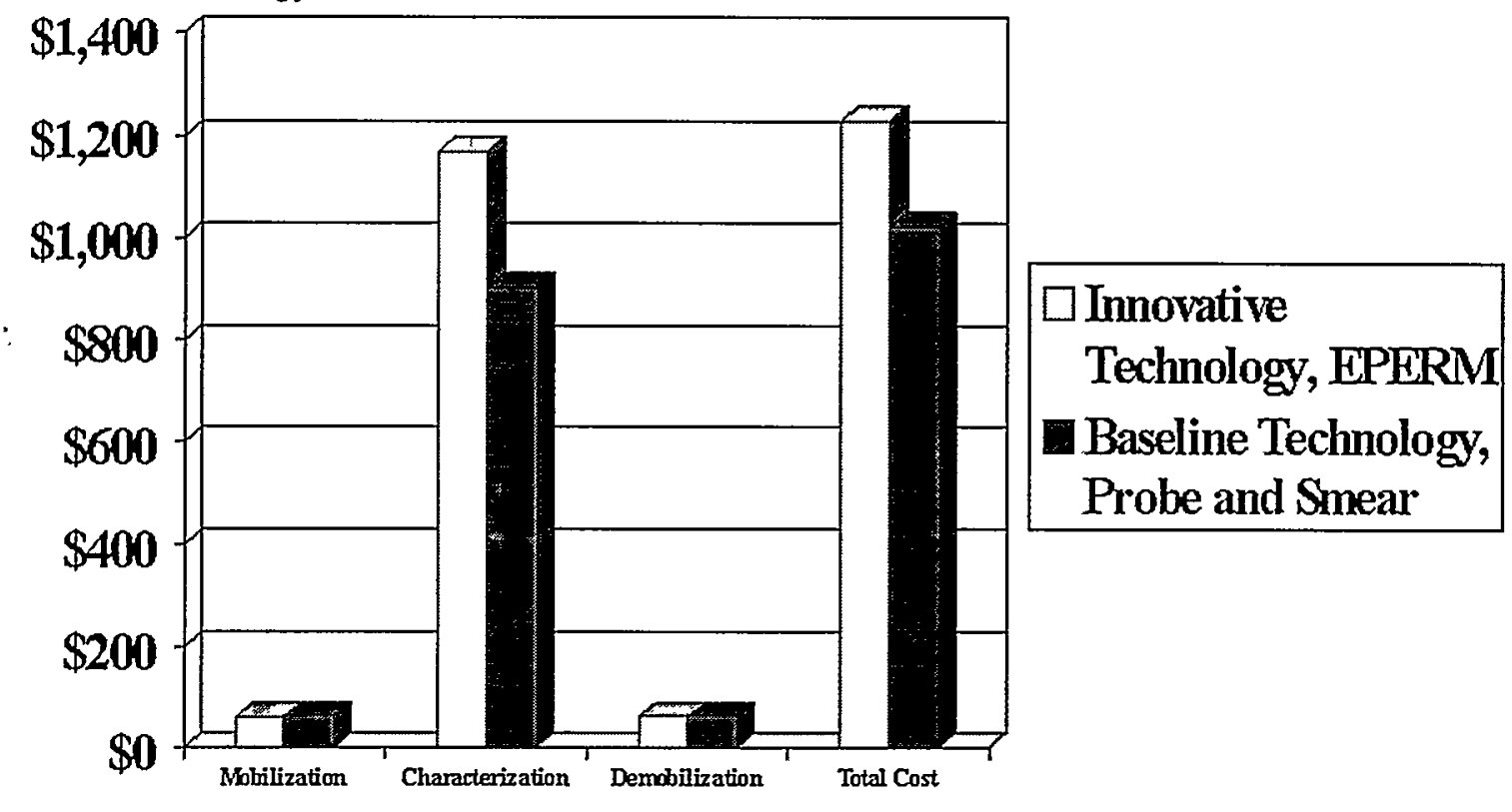

Figure 5. Estimated Cost Summary

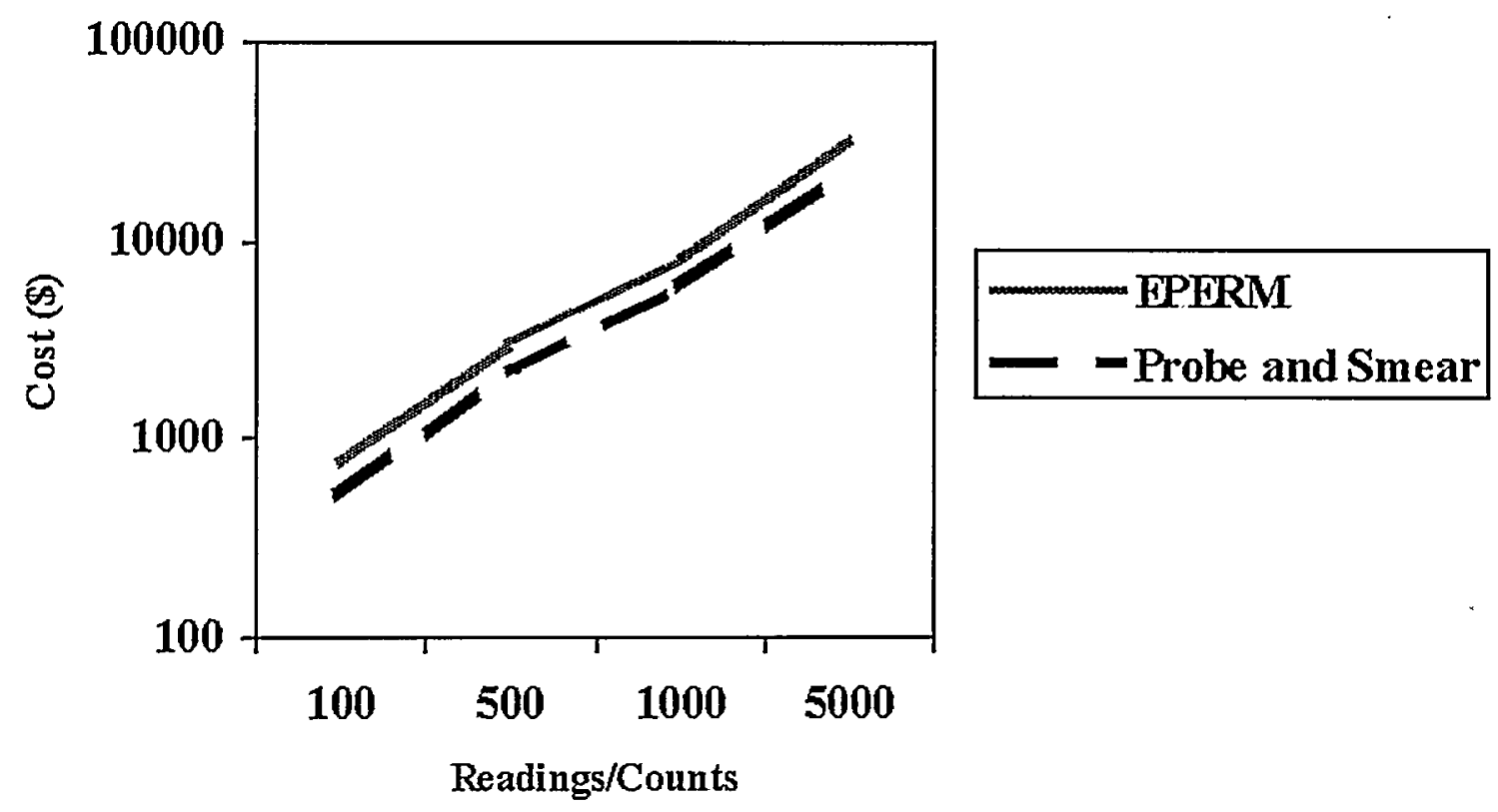

Figure 6. Projected Cost Comparison 


\section{Cost Conclusions}

The baseline technology does offer small cost savings over the innovative technology. The total cost for the two comparative demonstrations are \$1,193.81 (Innovative) and \$1,022.32(Baseline). The innovative technology is based on 178 readings. The EICs are hand carried and dispersed and retrieved. The baseline data is based on 207 readings. To give a meaningful comparison the innovative and baseline data are evaluated on a unit cost. This does not alter the unit productivity. The unit costs per reading are $\$ 6.04$ and $\$ 4.36$ (innovative vs. baseline).

The innovative technology is approximately $38 \%$ higher than the baseline technology. The reason for the cost difference is that there is no equipment expense shown for the baseline technology. The equipment cost is embedded in the hourly rate for the health protection technician. The innovative technology equipment cost is arrived by assuming that each electret will have a life of 15 readings and that a typical exposure time is one hour. The cost for the electret reader and equipment is prorated at $\$ 0.44 / \mathrm{Hr}$ and electret at $\$ 1.13 /$ reading. This equates to approximately $\$ 1.57$ per hour.

The innovative technology however does offers more flexibility over the baseline technology. The EICs can be reused many times, workers do not handles swipes, and the EICs can be left out for longer periods to give accurate background checks/readings. There is less chance for contamination of equipment and workers with the innovative technology. 


\section{SECTION 6}

\section{REGULATORY AND POLICY ISSUES}

\section{Regulatory Considerations}

There are no Comprehensive Environmental Response, Compensation, and Liability Act (CERCLA) or other regulatory considerations related to this technology.

The use of this technology as an alternative to the baseline technology requires approval by responsible site or facility health physics departments. 


\section{SECTION 7}

\section{LESSONS LEARNED}

\section{Implementation Considerations}

- After the initial electret reading, the final reading of a measurement becomes the initial reading of the next measurement. If the time span between the measurements is lengthy, the electrets may lose voltage charge due to background or other radiation fields and must be re-read before using again.

- During normal use, the electret may attract dust and other small particles that may cause erroneous readings. Pressurized dry air or nitrogen is recommended for removing these particles.

- Do not touch the Teflon ${ }^{\circledast}$ surface of the electret. Touching will discharge the electret and it will be useless.

- Electret exposure times should be estimated to reduce overexposure or underexposure. This can be done by estimating radiation levels from previous surveys or experience, or by periodic electret readings after placement. The SPER1 reader is easily carried to areas of deployment for making periodic readings. Either way may prevent the complete discharge of an electret and no useful data.

- The EPERM technology can be used most efficiently both in areas where access with the baseline technology is limited or difficult (e.g., overheads, gloveboxes), and for final surveys of areas using the MARSSIM guidelines.

\section{Technology Limitations and Needs for Future Development}

The E-PERM ${ }^{\circledast}$ technology has potential application for measuring alpha contamination in pipes and on the surfaces of small items. A system designed to provide flowing air through contaminated pipe coupled with a chamber to contain the ions and hold the electret would provide an inexpensive monitor. A similar system with a chamber to hold tools or small items and a second ion chamber could do the same for small items.

The software that allows the downloading of data, stored in the SPER2 microprocessor, to a PC should be updated and made more user friendly.

Limitations of the EIC are as follows:

- Surfaces where the EICs are placed should be relatively flat and smooth to form an enclosed space with the EIC. Gaps between the EIC and surface being monitored may cause erroneous readings. 


\section{APPENDIX A}

\section{REFERENCES}

Dua, S. K., P. Szerszen, R. Rose, J. Boudreaux, M. A. Ebadian, C. May, S. Salaymeh, and K. Kasper, 1999. Evaluation of Electret Ion Chambers for Measurement of Surface Alpha Contamination in Preparation for SRS-LSDDP. Paper presented at $2^{\text {nd }}$ Topical Meeting on Decommissioning, Decontamination, \& Reutilization of Commercial and Government Facilities, September 1999.

Meacham, S. A., P. Kotrappa, and L. Stieff, 1999. Field Evaluation of the Rad Elec Inc's E-PERM Alpha Monitoring System.

Stieff, Lorin and Paul Kotrappa, 1997, Application of Passive Integrating Electret Ion Chambers for Expedited Facility Characterization. Paper presented at X-Change '97, December 1997.

Westinghouse Savannah River Company, 321-M Large Scale Demonstration and Deployment Project, Demonstration Test Plan, E-Perm® Electret lonization Chambers, March, 1999. 


\section{APPENDIX B}

\section{TECHNOLOGY COST COMPARISON}

\section{Introduction}

The analysis in this appendix presents realistic cost comparisons between an innovative Alpha Electret Detection (EPERM) technology and the baseline probe and smear technology. The baseline uses a hand probe and surface smear technique to evaluate surface contamination levels. The innovative technology uses an electret ionization chamber (EIC). This chamber contains an electrically charged electret. As the EIC contacts negatively charged ions, its charge is reduced. This reduction in charge is measured and correlated to a contamination level.

The selected activities being analyzed comes from Hazardous, Toxic, Radioactive Waste Remedial Action Work Breakdown Structure and Data Dictionary (HTRW RA WBS), USACE, 1996. The HTRW RA WBS, developed by an interagency group, was used in this analysis to provide consistency with the established national standards.

Some costs are omitted from this analysis so that it more realistically reflects a typical commercial application. The general and administrative (G\&A) markup costs for the site contractor managing the demonstration are omitted from this analysis. Overhead rates for each DOE site vary in magnitude and in the way they are applied. Decision-makers seeking site-specific costs can apply their site's G\&A rate to this analysis without having to first back out the rates used at SRS.

The following assumptions were used as the basis for the innovative technology cost analysis:

- Oversight, engineering, quality assurance, and some administrative cost for the demonstration were not included.

- As applicable, equipment hourly rates for innovative and baseline pieces of equipment reflect government ownership, and are based on general guidance contained in the Office of Management and Budget's (OMB) Circular No. A-94 for Cost Effectiveness Analysis.

- Equipment unit rates are determined based on information recorded in the ACOE data collection forms.

- Standard labor rates established by the Savannah River Site for estimating D\&D work were used for the work performed by local crafts.

- The analysis expresses all work on a per-square-foot basis. 


\section{MOBILIZATION (WBS 331.01)}

Perform Electret Voltage Reading (Initial): SRS labor to read the initial electret voltage, record data.

\section{CHARACTERIZATION ACTIVITY - (WBS 331.02)}

Place Electrets: SRS labor to place electrets in desired location to measure contamination levels.

Remove Electrets: SRS labor to retrieve placed electrets.

Perform Electret Voltage Readings (Final) and Prepare Reports: SRS labor to read the final voltage from the electrets, record data and prepare contamination report.

Don/Removal of Personnel Protective Equipment, (PPE): Don and remove PPEs as required to perform work in a CA.

\section{DEMOBILIZATION (WBS 331.21)}

Clear and Remove Equipment from Radiation Area: SRS labor to decontaminate/clear and remove equipment from $\mathrm{CA}$.

The details of the cost analysis for the innovative and baseline technologies are summarized in Table B-1 and B-2. 
Table B-1. Innovative Technology E-Perm Cost Summary

\begin{tabular}{|c|c|c|c|c|c|c|c|c|c|c|c|}
\hline \multirow[t]{2}{*}{ Work Breakdown Structure (WBS) } & \multicolumn{2}{|c|}{ Labor } & \multicolumn{2}{|c|}{ Equipment } & \multirow[t]{2}{*}{ Other } & \multirow[t]{2}{*}{ Total Unit Cost } & \multirow{2}{*}{$\begin{array}{l}\text { Total Quantity } \\
\text { (TQ) }\end{array}$} & \multirow{2}{*}{$\begin{array}{l}\text { Unit of } \\
\text { Measure }\end{array}$} & \multirow{2}{*}{$\begin{array}{l}\text { Total Cost } \\
\text { (TC) }\end{array}$} & \multirow[t]{2}{*}{ Crew } & \multirow[t]{2}{*}{ Comments } \\
\hline & Hrs & Rate & Hirs & Rate & & & & & & & \\
\hline $\begin{array}{l}\text { Mobilization } \\
\text { (WBS 33.01) }\end{array}$ & & & & & & & & & $\$ 58.89$ & & \\
\hline $\begin{array}{l}\text { Perform Electret Vollage Readings } \\
\text { (Initial) }\end{array}$ & 0.0174 & $\$ 60.00$ & 0.0174 & $\$ 0.44$ & & $\$ 1.05$ & 56 & Each & $\$ 58.89$ & 1HP Tech & \\
\hline $\begin{array}{l}\text { Characterization } \\
\text { (WBS 331.02) }\end{array}$ & & & & & & & & & $\$ 1,074.91$ & & \\
\hline Place Electrets & 0.02 & $\$ 60.00$ & & & $\$ 1.57$ & $\$ 2.77$ & 178 & Each & $\$ 493.06$ & 1HP Tech & $\begin{array}{l}\text { "Other" cost for electret } \\
\text { use }\end{array}$ \\
\hline $\begin{array}{l}\text { Don/Removal of Personal Protective } \\
\text { Equipment, (PPE) }\end{array}$ & 0.8 & $\$ 60.00$ & & & $\$ 13.16$ & $\$ 61.16$ & 2 & $\overline{\text { Day }}$ & $\$ 122.32$ & $1 \mathrm{HP}$ Tech & $\begin{array}{l}\text { Other Rate is PPE, } \\
\$ 22.60 / d a y\end{array}$ \\
\hline Remove Electrets & 0.013 & $\$ 60.00$ & & & & $\$ 0.78$ & 178 & Each & $\$ 138.84$ & $1 \mathrm{HP}$ Tech & \\
\hline $\begin{array}{l}\text { Perform Electret Voltage Readings } \\
\text { (Final) and Prepare Reports }\end{array}$ & 0.0299 & $\$ 60.00$ & 0.0174 & $\$ 0.44$ & & $\$ 1.80$ & 178 & Each & $\$ 320.69$ & $1 \mathrm{HP}$ Tech & \\
\hline $\begin{array}{l}\text { Demobilization } \\
\text { (WBS 331.21) }\end{array}$ & & & & & & & & & $\$ 60.00$ & & \\
\hline $\begin{array}{l}\text { Clearing and Removing Equipment } \\
\text { from Radiation Area }\end{array}$ & 1 & $\$ 60.00$ & & & & $\$ 60.00$ & 1 & Each & $\$ 60.00$ & 1 HP Tech & \\
\hline Total Cost & & & & & & & & & $\$ 1,193.81$ & & $\begin{array}{l}\text { Total Cosi for the } \\
\text { Demonstration }\end{array}$ \\
\hline
\end{tabular}

\section{NOTES:}

1. TC $=U C X T Q$ (where TC $=$ total cost, $U C=$ unit cost, and TQ = total quantity), LS = Lump Sum

2. Labor Rates are $\$ 60.00 / \mathrm{hr}$ for Health Protection (HP) Technician

3. Capital Equipment rates for the Electret Reader and lon Chambers. These items have an unlimited life and are assumed to have a 5-year useful life. The Electrets are assumed to have an average life of 15 uses. 
Table B-2. Baseline Technology Probe and Smear

\begin{tabular}{|c|c|c|c|c|c|c|c|c|c|c|c|}
\hline \multirow[t]{2}{*}{ Work Breakdown Structure (WBS) } & \multicolumn{2}{|c|}{ Labor } & \multicolumn{2}{|c|}{ Equipment } & \multirow[t]{2}{*}{ Other } & \multirow[t]{2}{*}{ Total Unit Cost } & \multirow{2}{*}{$\begin{array}{l}\text { Total Quantity } \\
\text { (TO) }\end{array}$} & \multirow{2}{*}{$\begin{array}{c}\text { Unit of } \\
\text { Measure }\end{array}$} & \multirow{2}{*}{$\begin{array}{l}\text { Total Cost } \\
\text { (TC) }\end{array}$} & \multirow[t]{2}{*}{ Crew } & \multirow[t]{2}{*}{ Comments } \\
\hline & Hrs & Rate & Hrs & Rate & & & & & & & \\
\hline $\begin{array}{l}\text { Mobilization } \\
\text { (WBS 33.01) }\end{array}$ & & & & & & & & & $\$ 60.00$ & . & \\
\hline $\begin{array}{l}\text { Prepare Instruments/Mobilize to } \\
\text { work area }\end{array}$ & 1 & $\$ 60.00$ & & & & $\$ 60.00$ & 1 & LS & $\$ 60.00$ & 1HP Tech & \\
\hline $\begin{array}{l}\text { Characterization } \\
\text { (WBS 331.02) }\end{array}$ & & & & & & & & & $\$ 902.32$ & & \\
\hline Probe/Smear & 0.02174 & $\$ 60.00$ & & & & $\$ 1.30$ & 207 & Each & $\$ 270.00$ & 1HP Tech & $\begin{array}{l}\text { Equipment Cost included } \\
\text { in HP Labor Rale }\end{array}$ \\
\hline Count Smears & 0.1691 & $\$ 60.00$ & & & & $\$ 1.01$ & 207 & Each & $\$ 210.00$ & 1HP Tech & $\begin{array}{l}\text { Equipment Cost included } \\
\text { in HP Labor Rate }\end{array}$ \\
\hline Prepare Reports & 5 & $\$ 60.00$ & & & & $\$ 300.00$ & 1 & Day & $\$ 300.00$ & 1 HP Tech & \\
\hline $\begin{array}{l}\text { Don/Removal of Personal Protective } \\
\text { Equipment, (PPE) }\end{array}$ & 0.8 & $\$ 60.00$ & & & $\$ 13.16$ & $\$ 61.16$ & 2 & Day & $\$ 122.32$ & 1HP Tech & $\begin{array}{l}\text { Other rate is PPE, } \\
\$ 22.60 / \text { day }\end{array}$ \\
\hline $\begin{array}{l}\text { Demobilization } \\
\text { (WBS 331.21) }\end{array}$ & & & & & & & & & $\$ 60.00$ & & \\
\hline Clear Instruments from Area & 1 & $\$ 60.00$ & & & & $\$ 60.00$ & 1 & LS & $\$ 60.00$ & 1HP Tech & $\begin{array}{l}\text { Equipment Cost included } \\
\text { in HP Labor Rate }\end{array}$ \\
\hline Total Cost & & & & & & & & & $\$ 1,022.32$ & & $\begin{array}{l}\text { Total Cost for the } \\
\text { Demonstration }\end{array}$ \\
\hline
\end{tabular}

\section{NOTES:}

1. TC $=U C \times T Q$ (where $T C=$ total cost, $U C=$ unit cost, and $T Q=$ total quantity), $L S=$ Lump Sum

2. Labor Rates are $\$ 60.00 / \mathrm{hr}$ for Health Protection (HP) Technician

3. Equipment rates are considered part of the HP Tech. Hourly rate. 


\section{APPENDIX C \\ U \\ ACRONYMS AND ABBREVIATIONS}

\section{Acronym/Abbreviation}

CA

$\mathrm{CCR}$

DOE-SR

EIC

FDD

LC

LLW

LSDDP

PC

RBA

RCO

$\mathrm{SC}$

SRS

SRTC

TCR

USACE

WSRC

\section{Description}

Contamination area

Component Cleaning Room

Department of Energy - Savannah River

Electret lonization Chamber

Facilities Decommissioning Division

Large ionization chamber

low level waste

Large Scale Demonstration and Deployment Project

Personal Computer

Radiological Buffer Area

Radiological Control Operations

Small ionization chamber

Savannah River Site

Savannah River Technology Center

Tube Cleaning Room

U. S. Army Corps of Engineers

Westinghouse Savannah River Company 